\title{
Partnership For Peace, Tackling The Threats And Raising The Prospects For Justice In Rivers State
}

\author{
Fidelis Allen \\ Associate Professor and Acting Director \\ University of Port Harcourt Centre for Conflict and Gender Studies \\ Choba, Port Harcourt, Rivers State, Nigeria
}

\begin{abstract}
United Nations World Peace Day 2015 was marked with the theme, Partnership for Peace: Dignity for All. This is significant in many ways. First, it drew the attention of civil society groups, governments and all in positions of authority to the urgent need for strengthening inclusive security decision-making in a world peppered with violent conflict. Second, deep reflection on the human condition as the basis of analysis of any effort at securing lives and properties, and ensuring peace at the domestic and global fronts, was again brought to the fore. It sent a powerful message: global quest for peace in a world, increasingly threatened by injustice. The paper argues that injustice lies at the heart of many violent conflicts. Elite greed, struggle for power and sharp social and economic inequality in society, have promoted human conditions that are conducive to disharmony, disorder and wars. Meanwhile, peace cannot be secured by increased funding for the purchase of ammunitions or weapons of war alone. To reduce violent conflict, crime and rebellion, the question of economic, social and political inequality has to be addressed. Peace is the result of commitment of all to justice, which has to be defined in terms of respect for human rights and responsiveness to human security needs. Furthermore, which is the main point of this paper, collaborative tackling of threats to peace is a crucial element in securing justice in a society like Rivers State, where many social, political and economic tendencies have played out in recent times.
\end{abstract}

Key Words: Partnership. Peace. Threats. Justice. Rivers. State.

\section{INTRODUCTION}

On 19 September 2015, the final day of a training workshop on policy advocacy at the University of Port Harcourt, attended by members of the Rivers State Conflict Management Alliance, one participant narrated a sad story in course of the breakfast informal discussion. It was a life story of gunshot bullet that travelled all the way from an unknown point into the body of a sleeping lad in his parent's apartment in Port Harcourt, where unusual incidents that impact on personal and collective security seem to have intensified since politics turned sour prior to the 2015 elections. The boy was rushed to the hospital. Fortunately, he is alive today. A similar occurrence on 24 December 2015, killed a woman on board Keke (tricycle) from Okilton Bus Stop to Wimpey/Iwofe junction, Ada George Road.

Kidnapping, which once served as a strategy for natural resource nationalism among aggrieved militants in the Niger Delta, is now cheaply utilized by criminal gangs looking for money (Akpan 2010: 33). The media carry regular stories of these incidents. Friends, neighbours, colleagues and acquaintances have been victims. In some parts of the state such as Ahoada, Ogba-Egbema, Etche, Emohua and so on, expensive jokes such as threat of kidnap are common as it has become routine to find someone who has either been kidnapped or knows a close person who has been kidnapped. The trauma and fear that seethes within the consciousness of residents remain devastating. Three months ago, a young man returning from work, had hardly 
entered his home when armed young men followed, and shot several bullets at him. He was left in a pool of blood. He died before the wife could reach hospital.

There is no question that insecurity in Rivers State, before and after the 2015 elections is a troubling issue. Cases of inter and intra-cult clashes, kidnapping, armed robbery and sustained struggle for political power and influence among political elites have continued to make residents jumpy. Many have died from these activities.

On the global scene, people are watching with a sense of amazement the flood of refugees from war-torn countries (including Syria and Libya) into Europe in search of safety. The bloodcurdling movements with many, mostly children, dying along the way, reinforce the conviction that a peaceful world is urgent. They also remind world leaders of the need for them to be proactive in handling issues that easily lead to large-scale violence. Rather than seek peace on the basis of justice, political leaders seem to have been pursuing goals that do not promote peace or are insensitive to conflict.

The Niger Delta is a hot-blooded region. Despite crash in the price of oil on the global scene, the product, which has continued to serve as the economic mainstay of Nigeria for decades, is extracted in this region. At the same time, the industry is a key point of grievance among those who continue to feel a sense of exclusion from adequate financial benefits from the production and export of the oil---local communities. Women, men, youth and children have suffered different degrees of impact from the activities of oil and gas companies. Oil spill and gas flaring are the major causes of pollution in many conflict-ridden communities of the region. In part, the emergence of armed groups that fought oil companies and government security in the 1990s is linked to pollution, marginalization and structural issues in the governance of the oil economy. The region has remained volatile.

The theoretical narrative of change that focuses on collaborative efforts at addressing these problems demands tools and opportunities for collective understanding and handling of grievances. Against this backdrop, this paper seeks to achieve three objectives: explain what Partnership for Peace for the Dignity of All means to those working for a peaceful Rivers State; identify threats to peace and security in the state, and explain the imperative of tackling the threats from the perspective of partners. Finally, the paper makes recommendations to parties involved in the management of conflict in the state.

\section{Partnership For Peace}

As the theme or the World Peace Day suggests, we have to strengthen our envisioning of a world where every one can work towards the type of peace that is based on justice and dignity for all. In other words, in such a world, every one or group, including the state, can be an agent of peace. Simply, to partner, in this context, would mean collaboration, association or coming together of governments, communities, nongovernmental organizations, and so on, under a common vision of peace through delivery of justice and respect for the dignity of humanity. This, in my view, requires explanation of the correlate concept of peace, which many policymakers and political leaders have either deliberately misinterpreted or misapplied in their efforts to tackle violent conflict. Some have even triggered violent conflicts by interventionist efforts in citizens' socio-economic and political conditions.

We have to broaden our understanding of peace beyond the usual error of restricting it to the absence of physical violence, which Johan Galtung refers to as negative peace (Galtung 1964:1). This alone cannot constitute durable peace, especially if injustice characterizes society. His notion of positive peace places the absence of physical violence and structural violence as 
ingredients. The objective reality however, in a world consistently under intense pressure for violence and structural issues of unjust laws and their applications by rulers, along with oppressive state systems, add to the difficulty in realizing Galtung's ideal peace. This, in a way, contributes to the image of peace as a mere normative concept meant to drive aspirations toward a less violent world (Grewal 2003). It seems Galtung himself understood and appreciated this difficulty in his subsequent writings. Peace cannot be seen merely in terms of absence of material violence in a society where citizens are faced with severe economic, social, environmental, and political problems that limit their humanity. It has to look at the structure of society, as to whether unjust laws and their application have any role to play in generating painful socio-economic and political conditions. This link makes a lot of sense, as issues of human security are integral to the human quest for a world that is less acrimonious and less physically violent.

Peace theory, as seen in Galtung and Matsuo's writings, points to two dimensions of peace: peace value and peace sphere (Matsuo 2005). The former refers to the substance or content of peace, whereas the later has to do with views about those who make peace-agency (Galtung 1969: 167). Regarding peace value, early studies in the field easily saw peace as the absence of war. By this notion, peace is assumed to be in place if there is no war. The atmosphere of desire for prevention of another World War after the second was influential in the perception of those who saw peace as the absence of war. It would shortly become clear that between 1945 and 1960, there was no Third World War, yet developing countries, especially those emerging from colonial control, had come under increasing economic hardship. Gaps between the developed countries and developing countries had started becoming wider with the results of query as to why this was happening. Growing poverty and underdevelopment in the developing world soon convince some scholars that these were clear signs of peacelessness (Dasgupta 1968). In any case, the classical and narrow view of peace which ignore these conditions, will not go away soon. It has continued to inform how states respond to certain threats to national security.

Galtung wrote about three types of peace sphere: Universalist, in-group/out-group and inward oriented. The Universalist view sees the peace of the entire world as crucial. The conceptualization of an annual UN World Day for Peace proceeds from this mindset, as it places importance on the need for all to work for a peaceful world. It has a key element of multilateralism intended to benefit the world. It suggests that violent conflicts in any part of the world should be the concern of the whole world. On the other hand, an in-group/outgroup notion of peace sphere would see peace within groups as the crucial point. Too often, political, economic and social factors underlie the classification of groups with focus on the peace of in-groups. Only little interest is placed on the peace of the out-group.

An inward notion of peace sphere refers to the state of the individual mind. The individual is the object of peace. My conclusion about these notions of sphere of peace is that a much wider scope is imperative. For example, in the spirit of the human security framework, non-human elements of environment are part of the peace and security discourses.

\section{Tackling Threats to Peace and Security}

We shall proceed by first laying out the relationship between peace and security. Both concepts have moved closer to each other, in terms of meaning and goal. State-centric peace issues in classical context entail protection of the state from external aggression. As noted earlier, the emphasis is on the security of the state. Peace and security then, depends mainly on the use of force. In any case, security has moved beyond the mere state-oriented conceptualization to 
focus on human security. The United Nations Commission for Human Rights defines human security as

...to protect the vital core of all human lives in ways that enhance human freedoms and human fulfillment. Human security means protecting fundamental freedoms freedoms that are the essence of life. It means protecting people from critical (severe) and pervasive (widespread) threats and situations. It means using processes that build on people's strengths and aspirations. It means creating political, social, environmental, economic, military and cultural systems that together give people the building blocks of survival, livelihood and dignity (Cited in Rubio-Marin, Ruth and Dorothy Estrada-Tanck 2013).

Apparently, this is a paradigm shift, away from concentration on the security of the state to that of individual and community. The social, economic and political concerns of citizens are by this shift given primary consideration in the response to threats. The use of force, which is common with tackling threats to state security, is undermined when it comes to dealing with human security. In any case, state security has to be complemented by human security in specific ways including protection and empowerment of people.

Tackling any threat to security requires identifying the threats. In Rivers State, socio-economic and political trends have gradually brought to the fore critical issues of inequality, unemployment, poverty, and proliferation of small arms and light weapons in the context of an oil-driven economy. Others include crisis of confidence in the judiciary to deliver justice without bias for or against parties in conflict, intra and inter-party rivalry, rising wave of environmental injustice, oil theft and illegal refining. These have posed a major threat to peace and security.

\section{INEQUALITY}

Inequality in areas of income, healthcare, access to livelihoods, education, political and economic opportunities have risen in Rivers State. Even gender inequality has continued to pose a threat to the advancement of women, when it comes to access to opportunities in many parts of the state. It is important to note that nation-wide, 50 percent of the Nigerian population live in poverty. The wealth of the nation is controlled by 10 percent of the population (Ngara et al 2014). This gap is socially injurious. It is more so, for states in the Niger Delta that have seen huge financial in-flows from federal allocations. The period between 1999 and last year alone saw huge allocations that ought to have significantly changed living conditions of majority of people in the region, through improved poverty reduction programmes and provision of basic social amenities such as water, affordable healthcare and so on. Not only are many struggling, especially youths, to maintain a balance between inequality and access to better life, majority in the state seem to have gradually come to associate inequality with the country's corrupt politics. Politics is more or less a profession for many who simply want to line their pockets with the oil money. Whereas it ought to be a game played in the interest of closing gaps in political and economic inequality. As Nick Galasso and Majorie Wood (2015) have argued, economic inequality is destructive and vulnerable to violent conflict.

\section{UNEMPLOYMENT}

Unemployment poses serious threat to peace and security. Until recently, in the last five years or so, Nigeria experienced consistent economic growth. The country earned more than $\$ 600$ billion within five-decades or so from production and sale of oil. Meanwhile, several hundreds of youth graduating from universities, polytechnics and colleges of education in the country 
continue to roam the streets of Port Harcourt. Youth unemployment everywhere in the world is a threat to security and stability of society. Unemployed youths are vulnerable to recruitment as foot soldiers to politicians and conflict entrepreneurs (Akinwumi 2006).

The first quarter of 2015 saw an increase in unemployment rate in Nigeria. It rose from 6.4 percent in the last quarter of 2014 to 7.50 percent. Unemployment is the number of people actively looking for job. It means the teaming population of young graduates roaming the streets in search of $\mathrm{f}$ jobs in Rivers State constitutes severe threat to security as this condition is closely connected to poverty. Any policy agenda for tackling insecurity therefore, has to include job creation.

\section{Greed of political class}

This manifests in attitudes of struggle for political power at the expense of peace of community. There are numerous instances of greed-motivated politics. Nothing best describes a situation where politicians struggle at all cost-including killing of opponents-- to secure political power. The expected material gains from political positions have led many to undermine morality and human dignity. Greed is one of the closest concepts to describe the intense longwinded scuffles for political advantage at the expense of peace and security in communities.

\section{Politicization of the judiciary}

The judiciary is often said to be the last hope of the common man. It would appear that whenever this hope is lost, violence becomes the choice. This seems to have been the case in Rivers State, when the courts were closed for several months. Rivers state has been marked by large number of cases of violent activities in the form of killing and kidnapping. Some of these problems are reflections of choices by people in dispute who simply prefer violence rather than follow conventional and democratic and peaceful methods of settling disputes. This is a threat to security.

\section{Poverty}

Poverty is a conducive condition for criminality and insecurity of which Rivers State has remained a good case, in spite of the fact that the state has been a key recipient of huge monthly financial allocation from the federal purse for years. Closing the growing poverty gap with increased attention on employment opportunities for youths and women is more than urgent. Neglecting the poor is risky.

\section{Cultism}

Cultism is key social malaise. Politicians-local, state and national-- are mainly responsible for the growing threat posed by cultism, for their role in encouraging young people to join through monetary incentives and promise of good times after elections. This is accompanied by drug and increased illegal use of small guns and light weapons. Many, both in rural and urban communities, dread cult groups for the fear of being killed. The implication on the growing culture of violence in the state means, communities have had to be faced with tensions resulting from violent shootings and killings between and among groups supported by politicians from different political parties. Meanwhile, the police and other security agencies continue to say they are doing their best to tackle the problem. In Nigeria, these agencies are controlled centrally from Abuja, as they are unitary in nature. Any political party in control of the executive arm of government would be expected to control the coercive instruments of the state. The growing culture of violence might in part be the result of a belief on the part of some actors, that conflicts can hardly be resolved favourably if the executive and judiciary are under 
the tight control of the ruling party. In a way, we have to be able to see the crucial economic argument, which lays bare economic motives for those dancing to the music played by politicians. Unfortunately, many of these politicians have become victims of fear as well as they are unable to control the monsters that they created.

\section{Proliferation of Small Guns and Light Weapons}

Nigerians were again alerted to the role of politicians in the proliferation of small guns and light weapons in 2014, months before the 2015 elections. The Director-General of the National Task Force on Small Arms and Light Weapons, Osita Okeke, accused then serving governors of using their private jets to import guns ahead of the elections (Akomolafe, and Onani. 2015). Although this was difficult to verify, the reality is, there are guns in the hands of young people who use them for criminal activities. This is a source of insecurity in the state. Where and how do people get these weapons? Media reports reveal that illegal importations of guns were carried out before the elections through the ports in Nigeria. It is interesting to note that poor unemployed youths who use these guns are hardly responsible for the importation.

\section{Militarization of Oil Producing Communities}

As with many natural resource dependent countries in Africa, militarization of the oil sector in Nigeria is an issue that has raised several questions about security. Government had depended on raw force to calm youths resisting oil companies and government officials on the basis of unresolved grievances. In 2009, members of armed groups who had undertaken violent campaigns against oil companies and the government were offered amnesty by the federal government. This action has helped to raise hope about already fallen volumes of production of the oil on which Nigerian governments have depended on for the bulk of their revenues and foreign exchange.

\section{CORRUPTION}

Corruption is a threat to peace and security because it deprives communities of vital resources that should ordinarily be injected into providing basic social amenities. When such resources are diverted or stolen by public officials, the net result would be failure of the state to respond adequately to the needs of citizens. This seems to have been the case with many states in the Niger Delta receiving huge financial allocations from the Federation Account monthly. However, current anti-corruption policies of the federal government are being interpreted as ethnically driven against the people of the region. This is a dangerous trend with implications on peace.

\section{Oil Pollution}

Oil related conflicts have dominated the Niger Delta for decades. It has even been said that the political, social and economic fabric of the Nigerian state is currently being configured by the industry, to the extent that it pays the bills and generates the bulk of money needed to run the state. This is not without huge social and environmental costs to communities hosting oil companies. Oil pollution threatens community livelihoods and survival of people who have historically depended on the environment for income. Pollution from illegal refining of oil is an additional burden worsening the situation.

\section{Prospects for Justice}

Government, communities and civil society have a crucial role to play. Tackling these threats requires collaboration at the level of policy formulation, implementation, monitoring and evaluation. With increased awareness on the part of all regarding collaborative security, we can hope for a better Rivers State. Human security has to be at the centre of response by government, groups, and individuals for a change in the direction of a just and peaceful society. 
Such a society has to work more intensely to reduce inequality and poverty as a basis for securing peace.

\section{CONCLUSION/RECOMMENDATIONS}

The paper has explained what collaborative security means in context of tackling threats to peace in Rivers State. The 2015 World Peace Day celebrations offered many nongovernmental organizations an opportunity to organize and send a powerful message of peace to the state, especially to those who have suffered economic and political violence. The paper has argued a human security framework, and need for partnership in securing a just society. Government, in collaboration with industry, donor organizations, communities and nongovernmental organizations, can create adequate employment opportunities for youth. This can be achieved through following the path of practical engagement of youths in small and fairly large-scale agriculture and manufacturing. The educational and vocational routes, which have suffered corruption and nepotism, can be improved upon through merit-based mechanisms for selection of youths.

\section{References}

Akinwumi, Olayemi. 2006.Youth Participation in Violence in Nigeria Since the 1980s, Colette D., Z. Beykont, C. Higson-Smith and L. Nucci (Eds) International Perspectives on Youth Conflict and Development, New York: University of Oxford Press, p. 73

Akomolafe, Bayo and Emmanuel Onani. 2015: Guns, guns everywhere... New Telegraph, February 17

Akpan, Nseabasi S. (2010) Kidnapping in Nigeria's Niger Delta: An Exploratory Study Journal of Social Sciences, 24(1): 33-42

Daniel, Soni. 2016. Militants give condition to stop bombings in N/Delta, Vanguard, 19

Dasgupta, Sugata .1968. "Peacelesness and Maldevelopment: A New Theme for Peace Research in Developing Nations," Proceedings of the International Peace Research Association Second Conference, Assen, The Netherlands: Koninklijke Van Gorcum \& Comp, vol.2, 19-42

Galtung, Johan .1969. "Violence, Peace, and Peace Research," Journal of Peace Research, 6(3), 167-191

Galtung, Johan. 1964. An Editorial, Journal of Peace Research, 1 (1) pp.1-4

Galtung, Johan .1969, Violence, Peace, and Peace Research, Journal of Peace Research, 6(3), 167-191

Galtung, Johan .1981. Social Cosmology and the Concept of Peace, Journal of Peace Research, 18(2), 183-199

Galasso, Nick and Majorie Wood. 2015. Africa: Eight Ways to Reduce Inequality, RiversStateNew.com (accessed 15 December 2015)

Grewal, Baljit Singh. 2003. Johan Galtung: Positive and Negative Peace, paper presented at School of Social Science, Auckland University of Technology, 30 August

Matsuo, Masatsugu .2005. Peace and Conflict Studies: A Theoretical Introduction, Hiroshima: Keisuisha

MATSUO, Masatsugu, Concept of Peace in Peace Studies: A Short Historical Sketch

file:///Users/fidelisallen/Downloads/conceptofpeace.pdf (accessed 19 September 2015).

Ngara, Christopher Ochanja; Esebonu, Edward Ndem; Ogoh, Augustine Ogbaji \& Orokpo, Ogbole F. E. 2014. Poverty, Inequality and the Challenges of Democratic Consolidation in Nigeria's Fourth Republic Journal of Good Governance and Sustainable Development in Africa, Vol. 2, No 1,

Rubio-Marin, Ruth and Dorothy Estrada-Tanck. 2013. Violence Against Women, Human Security, and Human Rights of Women and Girls, Reinforced Obligations in the Context of Structural Vulnerability, Aili, Mari Tripp, Mayra Marx Ferree and Christina Ewig (eds) Gender Violence and Human Security: Critical Feminist Perspectives, New York: New York University Press, p. 242 